\title{
Mycorrhizal Species, Root Age, and Position of Mycorrhizal Inoculum Influence Colonization of Cotton, Onion, and Pepper Seedlings
}

\author{
U. Afek, E. Rinaldelli, J.A. Menge, E.L.V. Johnson, and E. Pond \\ Department of Plant Pathology, University of California, Riverside, CA 92521 \\ Additional index words. Gossypium hirsutum, Allium cepa, Capsicum annuum, Glomus spp., growth
}

\begin{abstract}
The length of time required for vesicular-arbuscular mycorrhiza (VAM) colonization, the effect of root age, and the position of VAM inoculum with respect to the root system were tested on cotton (Gossypium hirsutum L.), onion (Allium cepa L.), and pepper (Capsicum annuum L.). Colonization of onion by Glomus deserticola began 3 days after inoculation and reached $50 \%$ of the total root length after 21 days. Colonization by G. mosseae and G. intraradices began after 12 days and attained $15 \%$ and $37 \%$, respectively, after 21 days. In cotton, colonization with G. deserticola and G. intraradices began 12 days following inoculation and increased to $20 \%$ and $18 \%$, respectively, after 21 days. Colonization of cotton by G. mosseae was poor. In pepper, colonization with G. deserticola, G. mosseae, and G. intraradices began 3, 6, and 6 days after inoculation and, after 21 days, reached $60 \%, 13 \%$, and $10 \%$, respectively. In a second experiment, rapid colonization by G. deserticola took place in 3-day-old onion seedlings and increased to $51 \% 3$ days after inoculation. Ten- and 17-day-old seedlings were far less responsive to VAM colonization but became highly infected at 30 days when new roots were produced. In a third experiment, inoculum placement 3 $\mathrm{cm}$ below seeds at planting in the field was the most effective for promoting colonization of cotton and onion by VAM. In fumigated field soil, mycorrhizae increased cotton growth an average of $28 \%$ when inoculum was applied below seeds compared to one- or two-sided band applications. Even in nonfumigated field soil, inoculum placed $3 \mathrm{~cm}$ below the seed and inoculum placed in a band at one side 2 weeks after planting significantly increased cotton growth. In onion, mycorrhizal inoculation improved growth in fumigated soil when it was placed below the seed, but did not stimulate growth in nonfumigated soil.
\end{abstract}

Mycorrhizal fungi increase nutrient uptake and growth of many plants (Dodd et al., 1983; Harley and Smith, 1983; Haas et al., 1987; Menge, 1983; Mosse, 1973). It is now feasible to introduce mycorrhizal fungi in the field as a modern agriculture practice, especially for crops planted in poor soil with few or no indigenous mycorrhizal fungi (Jeffries, 1987). While success in achieving effective mycorrhizal associations with crop plants growing in sterilized soil has been achieved, the ultimate success for agricultural use of vesicular-arbuscular mycorrhizal (VAM) fungi will occur when they can be used dependably to improve performance of crops grown in nonfumigated soil.

The effectiveness of VAM inoculum depends on the colonization potential of the inoculum (Alexander, 1965; Daniels et al., 1981; Haas and Krikun, 1985), proper placement (Afek et al., 1989; Menge and Timmer, 1982), proper timing (Smith et al., 1979), age of roots (Hepper, 1985), and the susceptibility of crops to VAM colonization (Hepper, 1985; Sanders et al., 1977). Total root colonization by VAM fungi is sometimes negatively correlated with the length of time between seed germination and the initial mycorrhizal infection (Afek et al., 1988; Smith et al., 1979). The purpose of this study was to determine the length of time required for colonization of cotton, onion, and pepper roots by VAM fungi under greenhouse conditions and to examine the efficiency of VAM colonization of cotton and onion in the field with respect to placement of the inoculum in the soil. The effect of root age on VAM colonization of onion root also was studied. All of these experiments were conducted in the continuing effort to improve growth responses of cotton,

Received for publication 6 Feb. 1990. This research was supported by a BARD grant (U.S.-Israel Binational Agriculture Research and Development Fund). We are grateful to Isfendiar Ramadan for soil analysis and to Doreen Alewine for typing the manuscript. The cost of publishing this paper was defrayed in part by the payment of page charges. Under postal regulations, this paper therefore must be hereby marked advertisement solely to indicate this fact. pepper, and onion to mycorrhizal inoculation in nonfumigated soil.

\section{Materials and Methods}

Plant material and VAM inoculum. Seeds of 'SJ-2' cotton, 'Burpee Yellow Glove' onion, and 'California Wonder' pepper were surface-disinfested with $20 \%$ sodium hypochlorite for 1 min and rinsed twice in distilled, sterilized water for 1 min each time before planting. These crops were chosen since they are annuals and responded positively to VAM colonization in previous studies (Afek et al., 1990). Sandy loam soil, which was used for both greenhouse and field experiments, was characterized as follows: $\mathrm{P}-9.5 \mathrm{ppm}$ by Olsen analysis (Chapman and Pratt, 1961), which is considered a low level (Graham and Leonard, 1982; Waterer and Coltman, 1989b); N-632 ppm (Schuman et al., 1973); Zn-12.8 ppm; Mn-8.6 ppm; Fe6.5 ppm; $\mathrm{Cu}-1.7$ ppm (Page, 1982); $\mathrm{Ca}-23.5 \mathrm{meq} / \mathrm{liter} ; \mathrm{Mg}-$ $3.8 \mathrm{meq} / \mathrm{liter}$; Na- $13.9 \mathrm{meq} / \mathrm{liter}$ K $-142 \mathrm{ppm}$; saturation percentage (SP) - 27\%; $\mathrm{pH}-7.7$; electroconductivity (EC) -4.0 $\mathrm{dS} \cdot \mathrm{m}^{-1}$; sodium adsorption ratio (SAR) - 3.8; exchangeable sodium percentage (ESP)-4.2\%; organic matter (OM)-O.80\%; clay- $8.3 \%$; silt-28.6\%; and sand-63.1\% (Quick and Rible, 1960). This soil, which was either fumigated or not fumigated with methyl bromide $(98 \% \mathrm{MB}+2 \%$ chloropicrin, equivalent to $500 \mathrm{~kg} \cdot \mathrm{ha}^{-1}$ ), was used for field trials with vegetable crops the previous 3 years of this study and was taken from an agricultural site at the Citrus Experiment Station, Univ. of California, Riverside. No fertilizers were used in the experiments. Plants were inoculated with the mycorrhizal fungi Glomus intraradices Schenck and Smith (isolate 185 collected from Citrus sp., Ventura, Calif., 1975); G. deserticola Trappe, Blosse and Menge (isolate 0-1 collected from Citrus sp., Thermal, Calif., 1975); or G. mosseae (Nicol. and Gerd.) Gerdemann and Trappe (isolate S-50 collected from Artemisia sp., Fresno, Calif., 1981). 
The inoculum for each mycorrhizal species consisted of mixed roots and soil from sudan grass (Sorghum vulgare Pers) nurse cultures that had been infected with the mycorrhizal fungus for 9 months. Inoculum potential of the mixture was calculated by the most probable number (MPN) procedures (Alexander., 1965; Daniels et al., 1981) and inoculum quantity adjusted so that inoculum potential was identical using Sudan grass as the host. Percent colonization by VAM was calculated, after staining in lactophenol trypan blue, as the number of colonized sites examined randomly per total sites x 100 (Phillips and Hayman, 1970).

Determination of the length of time for VAM colonization of cotton, onion, and pepper in the greenhouse (Expt. 1). Cotton, onion, and pepper were inoculated separately with the three VAM fungi (G. intraradices, G. deserticola, and G. mosseae) in soil autoclave twice for $1 \mathrm{hr}$ with a 24-hr interval between autoclavings. Mycorrhizal inoculation was achieved by placing $=10 \mathrm{~g}$ of inoculum $5 \mathrm{~cm}$ deep in $500-\mathrm{cm}^{3}$ autoclave clay pots containing the autoclave soil. Seven-day-old seedlings of cotton, onion, and pepper were planted in the pots with roots in contact with the inoculum. The pots were placed in a completely randomized design on a greenhouse bench at $24 \pm 2 \mathrm{C}$. Fluorescent light was provided to maintain a day length of $14 \mathrm{hr}$. Photosynthetically active radiation (PAR) within the 400- to $700-\mathrm{nm}$ range was periodically measured in terms of micromoles per second per square meter; it averaged $385 \pm 58$ (Graham and Leonard, 1982). Five plants were harvested every 3 days for 21 days, their roots stained and examined for percent VAM colonization. The experiment was run twice with similar results.

Onion root age and VAM colonization of onion (Expt. 2). Onion seeds were surface-sterilized in $20 \%$ sodium hypochlorite solution for $1 \mathrm{~min}$ and rinsed twice for $1 \mathrm{~min}$ each time in distilled, sterilized water. The seeds were then placed on damp filter paper in 9-cm-diameter petri dishes in an incubator at $24 \mathrm{C}$ to germinate. After 3 days, when the first root was $=0.5 \mathrm{~cm}$ long, 150 germinated seeds were planted into autoclave soil in an autoclave nursery flat, as described above. Simultaneously, 42 germinated seeds were planted into $21500-\mathrm{cm}^{3}$ clay pots (two plants per pot) containing autoclave soil; $10 \mathrm{~g}$ of $\mathrm{G}$. deserticola inoculum were placed in contact with the root system. The 150 plants in the nursery flat were grown for 7, 14, or 21 days. At the end of each time period, 42 plants were transplanted into 21 pots and inoculated with G. deserticola as already described. All plants were grown in a greenhouse at 24 $\pm 2 \mathrm{C}$. Fluorescent light was provided in addition to natural light (14-hr light period) as described for Expt. 1. Plants in three pots were harvested and root colonization estimated 3, 6, $9,12,15,18$, and 24 days after inoculation for each pre-inoculation period. The experiment was conducted twice with similar results. The experimental design was completely randomized after all pots from all time periods were mixed together.

Determination of efficiency of VAM colonization of cotton and onion with respect to placement of the inoculum in the field (Expt. 3). In May 1987, cotton and onion were planted in double $80-\mathrm{m}$ rows in methyl bromide-fumigated $(98 \% \mathrm{MB}+2 \%$ chloropicrin, equivalent to $500 \mathrm{~kg} \cdot \mathrm{ha}^{-1}$ ) and nonfumigated soil.

The field experimental design was a randomized block with four blocks. Each treatment contained a $1.5-\mathrm{m}$ row of onions and a $3-\mathrm{m}$ row of cotton. The width of the rows were $30 \mathrm{~cm}$. There were 13 to 16 plants in each plot. One plant from each treatment block was randomly harvested 3, 4, or 5 weeks after planting and its root system evaluated for VAM colonization.
The final harvest for total dry weight was done 16 weeks after planting. Treatments included: 1) control without mycorrhizal inoculation; 2) inoculation with G. deserticola $3 \mathrm{~cm}$ below seeds at planting; 3) inoculation with G. deserticola on one side of plant (5 cm deep, $3 \mathrm{~cm}$ from plant) 2 weeks after planting; 4) inoculation with $\mathrm{G}$. deserticola on both sides of plant $(5 \mathrm{~cm}$ deep, $3 \mathrm{~cm}$ from plant) 2 weeks after planting; 5) inoculation with $G$. intraradices $3 \mathrm{~cm}$ below seeds at planting; 6) inoculation with $G$. intraradices on one side of plant $(5 \mathrm{~cm}$ deep, 3 $\mathrm{cm}$ from plant) 2 weeks after planting; and 7) inoculation with $G$. intraradices on both sides of plant $(5 \mathrm{~cm}$ deep, $3 \mathrm{~cm}$ from plant) 2 weeks after planting. Banding was done by dispensing the inoculum by hand using $170 \mathrm{~g}$ inoculum $/ \mathrm{m}$ in each band. No fertilizers were used during the experiment.

Experiment 3 was performed once during Summer 1987, but similar field trials at two sites each in 1982 and 1983 had produced similar results.

\section{Results}

Determination of the length of time for VAM colonization of cotton, onion, and pepper under optimum conditions. Cotton. Colonization with $G$. deserticola and $G$. intraradices was detected 12 days after inoculation, attaining $20 \%$ and $18 \%$ after 21 days, respectively (Fig. 1). Colonization by G. mosseae was poor.

Onion. Colonization with G. deserticola was detected 3 days after inoculation and increased to $50 \%$ after 21 days (Fig. 2). Colonization. with G. mosseae began 12 days after inoculation and increased to $15 \%$ after 21 days. Colonization with G. intraradices also occurred by 12 days after inoculation and increased to $37 \%$ after 21 days.

Pepper. Colonization with G. deserticola was evident at 3 days after inoculation, and G. mosseae and G. intraradices at 6 days (Fig. 3). After 21 days, colonization with these fungi reached $60 \%, 13 \%$, and $10 \%$, respectively.

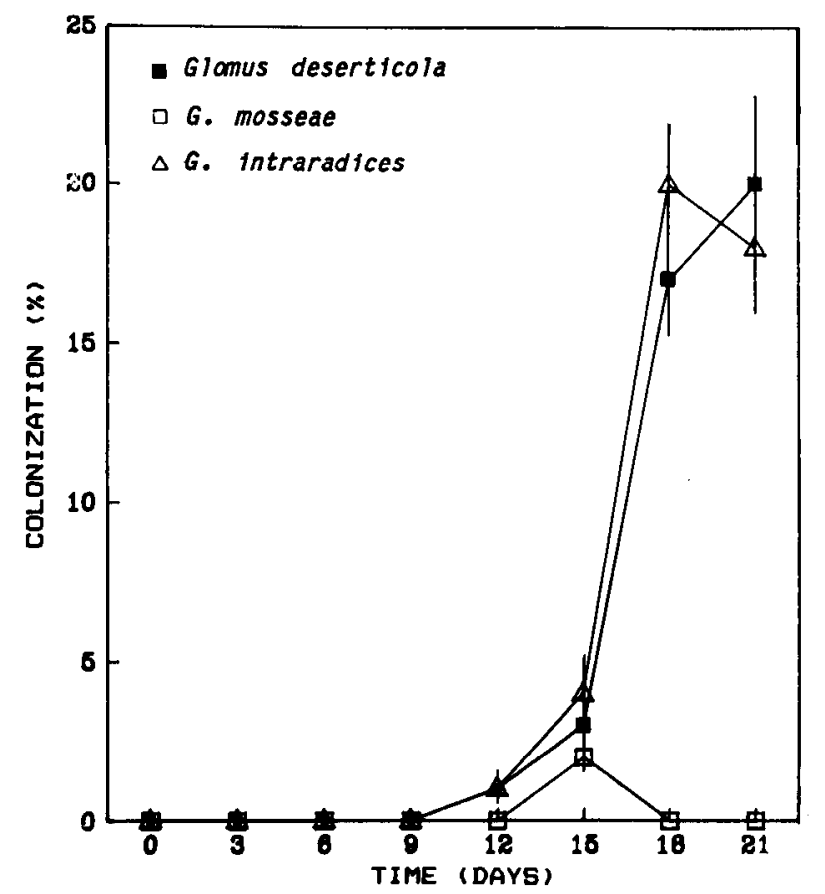

Fig. 1. Colonization of cotton 1 to 21 days following inoculation with Glomus deserticola, G. mosseae, and G. intraradices in autoclave soil. The vertical bars are standard errors. 


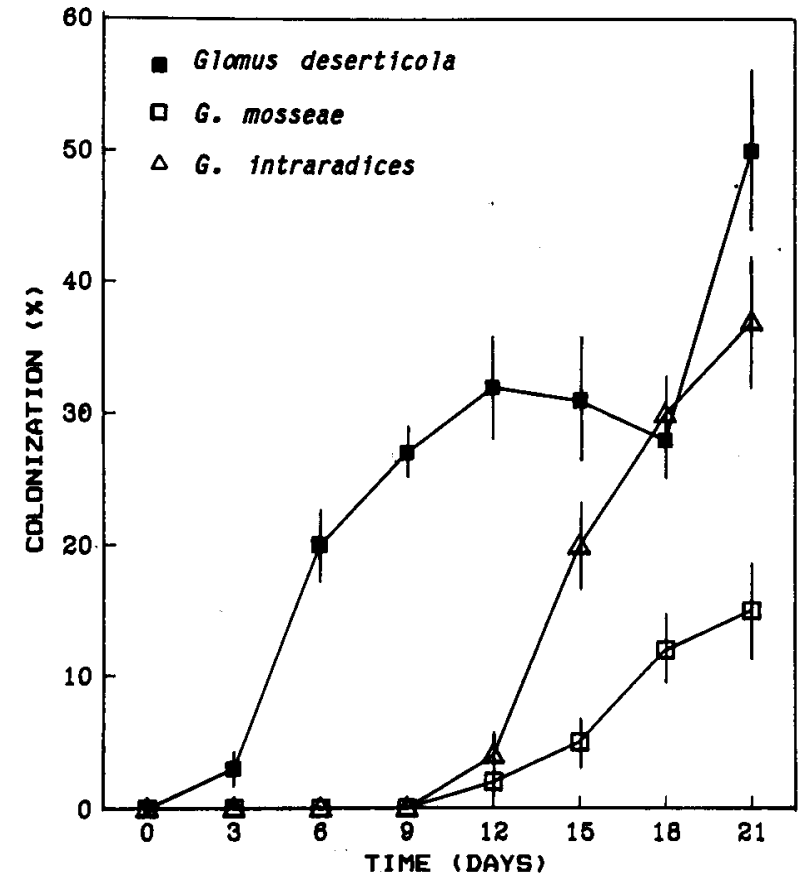

Fig.2. Côlonization of onion 1 to 21 days following inoculation with Glomus deserticola, G. mosseae, and G. intraradices in autoclaved soil. The vertical bars are standard errors.

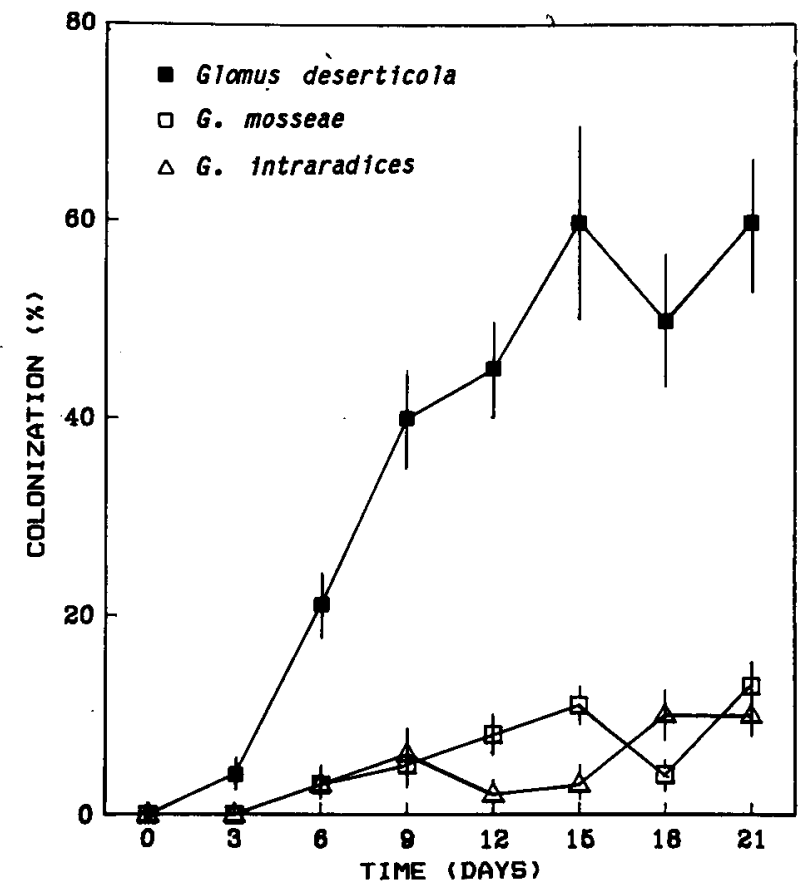

Fig. 3. Colonization of pepper 1 to 21 days following inoculation with Glomus deserticola. G. mosseae. and G. intraradices in autoclave soil. The vertical bars are standard errors.

The effect of onion root age on VAM colonization. Rapid colonization with G. deserticola took place in 3-day-old seedlings and reached 51\% 3 days after inoculation (seedling age 6 days) (Fig. 4). Ten- and 17-day-old seedlings were more resistant to VAM colonization. Twenty-four-day-old seedlings again had rapid colonization.

Determination of the efficiency for VAM colonization of cotton and onion with respect to placement of the inoculum in the

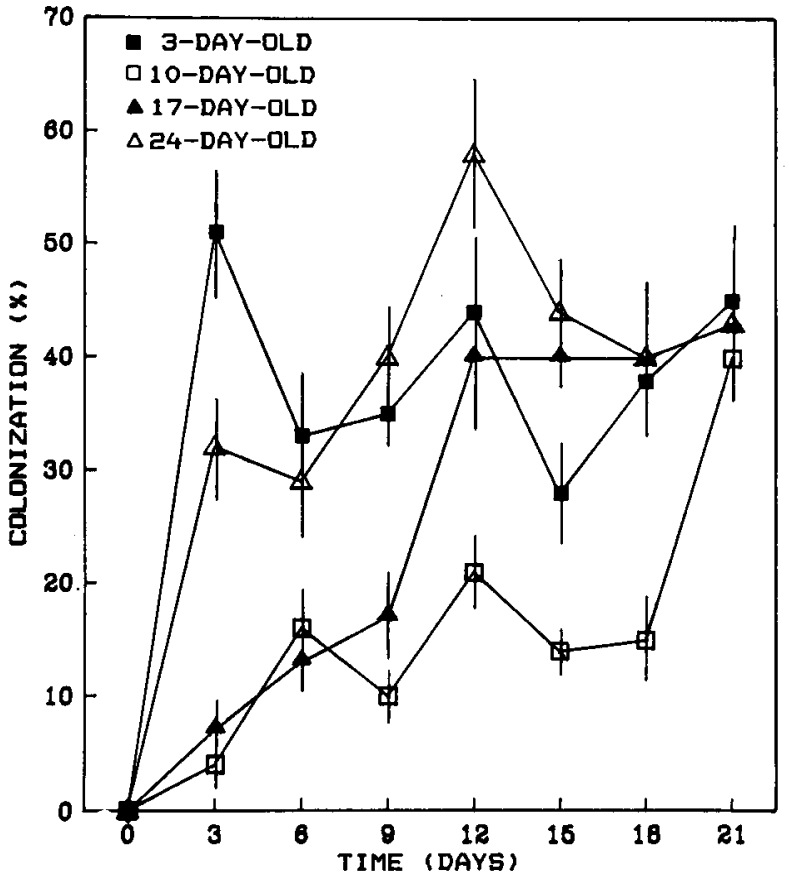

Fig.4. Colonization of $\hat{3}^{-}, 10 \overline{-}, 1 \overline{7}^{-}$, and 24 -day-old onion seedilings 1 to 21 days following inoculation with Glomus deserticola in autoclave soil. The vertical bars are standard errors.

field. Mycorrhizal colonization of cotton in fumigated soil was best for both G. deserticola and G. intraradices when inoculum was placed below seeds at planting, reaching $29 \%$ and $40 \%$, respectively, at 5 weeks after planting (Table 1). VAM colonization of onion in fumigated soil also was highest when inoculum was placed below the seeds at planting, reaching $32 \%$ and $59 \%$ for G. deserticola and G. intraradices, respectively, at 5 weeks (Table 1). Even in nonfumigated soil at 5 weeks after inoculation, with one exception, VAM colonization of onion and cotton reached a maximum when inoculum was placed below seeds at planting (Table 1).

Generally, in fumigated soil, dry weights of VAM-inoculated cotton and onion plants were significantly higher than those of noninoculated plants. Further, dry weights of cotton and onion plants from fumigated soil treatments were greatest when VAM inoculum had been placed below seeds at planting (Table 2). In nonfumigated soil, dry weights of cotton plants were increased by inoculation with G. deserticola and only when inoculum was placed below seeds at planting or banded on one side 2 weeks after planting. There were no significant differences among dry weights of onion in nonfumigated soil (Table 2).

\section{Discussion}

Today we have the technology to produce VAM inoculum and apply it as a biofertilizer. However, large-scale quantities of VAM for field application cannot be stored for long periods free of contamination, as the inoculum is maintained in nonsterile conditions (Menge, 1983; Menge and Timmer, 1982). The efficiency of such use has to be improved so that growth responses are assured with field applications. The effectiveness of VAM inoculum depends on the colonization potential of the inoculum, proper placement, proper timing, and the susceptibility of the crops to colonization.

Onion and cotton are known to respond to VAM inoculation (Afek et al., 1988). However, growth responses of these crops 
Table 1. The effect of method of mycorrhizal inoculation in the field on mycorrhizal colonization of cotton and onion in fumigated and nonfumigated soil after 5 weeks.

\begin{tabular}{lcccc}
\hline \hline & \multicolumn{2}{c}{$\begin{array}{c}\text { Cotton } \\
\text { (\% colonization) }\end{array}$} & $\begin{array}{c}\text { Onion } \\
\text { (\% colonization) }\end{array}$ \\
\cline { 2 - 5 } I n o c u 1 a t i o n & $1^{2}$ & 8 & 1 & 10 \\
Noninoculated & & & 32 & 32 \\
Glomus deserticola & 29 & 14 & 13 & 19 \\
$\quad$ Below seeds at planting & 5 & 8 & 7 & 19 \\
$\quad$ Band one side after 2 weeks & 4 & 26 & 59 & 35 \\
Band two sides after 2 weeks & & & 13 & 15 \\
G. intraradices & 40 & 20 & 19 & 14 \\
$\quad$ Below seeds at planting & 4 & 12 & 15.9 & 14.6 \\
$\quad$ Band one side after 2 weeks & 8 & 9 & & \\
$\quad$ Band two sides after 2 weeks & 9.6 & 15.1 & & Fonfumigated \\
LSD $(P=0.05)$ & &
\end{tabular}

${ }^{2}$ Each number is an average of four replicates,

Table 2. Dry weights of cotton and onion plants after 16 weeks of growth as affected by different methods of inoculation of mycorrhizal fungi and by soil fumigation in the field.

\begin{tabular}{|c|c|c|c|c|}
\hline \multirow[b]{2}{*}{ Inoculation } & \multicolumn{2}{|c|}{$\begin{array}{l}\text { Cotton } \\
\text { (g/plant) }\end{array}$} & \multicolumn{2}{|c|}{$\begin{array}{l}\text { Onion } \\
\text { (g/plant) }\end{array}$} \\
\hline & Fumigated & Nonfumigated & Fumigated & Nonfumigated \\
\hline Noninoculated & $14^{2}$ & 69 & 33 & 26 \\
\hline \multicolumn{5}{|l|}{ Glomus deserticola } \\
\hline Below seeds at planting & 118 & 157 & 65 & 37 \\
\hline Band one side after 2 week & ks 85 & 148 & 53 & 46 \\
\hline Band two sides after 2 week & ks 68 & 80 & 51 & 28 \\
\hline \multicolumn{5}{|l|}{ G. intraradices } \\
\hline Below seeds at planting & 106 & 94 & 65 & 37 \\
\hline Band one side after 2 week & ks 96 & 92 & 55 & 30 \\
\hline Band two sides after 2 weeks & 101 & 98 & 56 & 33 \\
\hline $\operatorname{LSD}(P=0.05)$ & 52.3 & 47.6 & 25.1 & 26.6 \\
\hline
\end{tabular}

'Each number is an average of four replicates.

in nonfumigated soils, where the VAM inoculum is competing with other microorganisms, has not been shown to occur effectively (Table 2). One of the keys to eliciting growth responses with VAM fungi in crops is" thought to be achieving rapid colonization (Haas et al., 1987; Manjunath et al., 1983). In these experiments, colonization of cotton, onion, and pepper occurred within 6 to 15 days under optimal conditions (Figs. 1-3). Under field conditions, comparable levels of colonization of cotton and onions rarely occurred even after 5 weeks in nonfumigated soils (Table 1). Rapid colonization must be realized in the field if growth responses are to be achieved. Attempts must be made to improve the rates of VAM colonization in the field to approach those achieved under greenhouse conditions. Colonization rates by VAM fungi are more rapid in fumigated soil than in nonfumigated soil (Table 1), indicating that competing microorganisms or native mycorrhizae in nonfumigated soil may affect the infection process (Afek et al., 1990). This situation may explain why, sometimes, unexpected results occur when inoculum banded on two sides is less effective than a single band (Table 2). One of the most important factors that influences VAM colonization of plants is the P level in the soil. Benefits of VAM fungi are greatest when crops are grown on P-deficient or P-fixing soils (Graham and Leonard, 1982; Waterer and Coltman, 1989a, 1989b). However, we chose a soil low in $\mathrm{P}$ (9.5 ppm; field and greenhouse experiments); this factor (probably) enhanced VAM colonization and growth response of the crops following inoculation with VAM.

Some VAM fungal species are more efficient on certain crops than on others (Daniels et al., 1981; Sanders et al., 1977). Differences in inoculum quality of different VAM species in comparative studies may be responsible for some of the reported differences in effectiveness between species or isolates. However, even in this study, where inoculum quantity was adjusted to achieve similar inoculum potentials, $G$. intraradices and G. deserticola were better colonizers, while isolate of G. mosseae was poor for all crops (Figs. 1-3). Thus, isolates which naturally produce rapid infection in crops should be selected for field work.

Inoculum placement has been shown repeatedly to be important for field crop growth responses (Afek et al., 1989; Jackson et al., 1972; Menge et al., 1977). A review of the literature (Menge and Timmer, 1982) indicates that layering inoculum beneath seeds so that roots will penetrate the inoculum appears to be more desirable than banding inoculum along the sides or placing inoculum with the seed. Similarly, results of this study show that maximum colonization of plants was achieved when VAM inoculum was placed below seeds at planting (Table 1).

The age and condition of crop roots have a major effect on rapid colonization by VAM inoculum and they are factors over which we have some control. Crop species also differ in the period of time over which their root systems will establish mycorrhizal associations (Hepper, 1985) and in the maximum proportion of the root system that can become mycorrhizal (Buwalda et al., 1982a, 1982b; Jakobsen and Nielsen, 1983; Warner and Mosse, 1982). We found that extensive VAM colonization took place in 3- and 30-day-old onion seedlings, whereas 10- and 
17-day-old onion seedlings were far less responsive to VAM colonization (Fig. 4). The reason for this appears to be the unique rooting habit of onion, whereby new flushes of roots are periodically produced at the base of the bulb and will pass through the VAM inoculum. These new roots are young, and VAM colonization fluctuates with each flush of young roots, as they have a high degree of susceptibility.

In normal root systems, the young, potentially colonizable roots are produced as branches from other roots (Hepper, 1985; Mosse, 1975). It then becomes critical for VAM inoculum to beat its optimum potential when the roots pass through because, at early age, they are strongly infected. Other investigators reported that VAM fungus colonization of root plants grown in the field occur outside the zone of inoculation at a secondary infection along the roots (Waterer and Coltman, 1989a, 1989b). However, mycorrhizal inoculum should be adjusted for maximum germination-maximum inoculum potential during the one short window of root susceptibility as the roots pass through the inoculum.

\section{Literature Cited}

Afek, U., J.A. Menge, and E.L.V. Johnson. 1988. Growth responses of field crops following inoculation with mycorrhizal fungi in fumigated and nonfumigated soil. Phytopathology 78:1567. (Abstr.)

Afek, U., J.A. Menge, and E.L.V. Johnson. 1990. The effect of Pythium ultimum and treatments with metalaxyl on root length and mycorrhizal colonization of cotton, onion and pepper. Plant Dis. 74:117120.

Afek, U., E. Rinaldelli, J.A. Menge, and E.LV. Johnson. 1989. The effect of root age and position of mycorrhizal inoculum on colonization of cotton, onion and pepper. Phytopathology 79:1138. (Abstr.)

Alexander, M. 1965. Most probable-number method for microbial population, p. 1467-1472. In: C.A. Black (cd.). Methods of soil analysis. Part 2, chemical and microbiological properties. Amer. Sot. Agron., Madison, Wis.

Buwalda, J. G., G.J.S. Ross, D.P. Stribley, and P.B. Tinker. 1982a. The development of endomycorrhizal root systems. III. The mathematical representation of the spread of vesicular-arbuscular mycorrhizal infection in root systems. New Phytol. 91:669-682.

Buwalda, J. G., G.J.S. Ross,.D.P. Stribley, and P.B. Tinker. 1982b. The development of endomycorrhizal root systems. IV. The mathematical analysis of effects of phosphate on the spread of vesiculararbuscular infection in root systems. New Phytol. 22:391-399.

Chapman, H.D. and P.F. Pratt. 1961. Methods of analysis for soils, plants and waters. Univ. of California Press, Berkeley.

Daniels, B. A., P.M. McCool, and J.A. Menge. 1981. Comparative inoculum potential of spores of six vesicular-arbuscular mycorrhizal fungi. New Phytol. 89:385-391.

Dodd, J., J. Krikun, and J.H. Haas. 1983. Relative effectiveness of indigenous population of vesicular-arbuscular mycorrhizal fungi from four sites in the Negev. Israel J. Bet. 32:10-21.

Graham, J.H. and R.T. Leonard. 1982. Interaction of light intensity and soil temperature with phosphorus inhibition of vesicular-arbuscular mycorrhizae formation. New Phytol. 91:683-690.

Haas, J.H. and J. Krikun. 1985. The efficacy of endomycorrhizalfungus isolates and inoculum quantities required for growth response. New Phytol. 100:613-621.

Haas, J. H., B. Bar-Yosef, J. Krikun, R. Barak, T. Markovitz, and S. Kramer. 1987. Vesicular-arbuscular mycorrhizal fungus infestation and phosphorus fertigation to overcome pepper stunting after methyl bromide fumigation. Agron. J; 79:905-910.

Harley, J.L. and S.E. Smith. 1983. Mycorrhizal symbiosis. Academic, London.

Hepper, C.H. 1985. Influence of age of roots on the pattern of vesicular-arbuscular mycorrhizal infection in leek and clover. New Phytol. 101:685-693.

Jackson, J. E., R.E. Franklin, and R.H. Miller. 1972. Effects of vesicular-arbuscular mycorrhizae on growth and phosphorus content of three agronomic crops. Soil Sci. Amer. Proc. 36:64-67.

Jakobsen, I. and N.E. Nielsen. 1983. Vesicular-arbuscular mycorrhizae in field grown crops. I. Mycorrhizal infection in cereals and peas at various times and soil depths. New Phytol. 93:401413.

Jeffries, P. 1987. Use of mycorrhizae in agriculture, p. 319-354. In: G.G. Stewart and L Russell (eds.). CRC critical reviews in biotechnology. CRC Press, Boca Raton, Fla.

Manjunath, A., R. Mohan, and D.J. Bagyarj, 1983. Response of citrus to vesicular-arbuscular mycorrhizal inoculation in unsterile soils. Can. J. Bet. 61:2729-2732.

Menge, J.A. 1983. Utilization of vesicular-arbuscular mycorrhizal fungi in agriculture. Can. J. Bot. 61:1015-1024.

Menge, J.A. and L.W. Timmer, 1982. Procedures for inoculation of plants with vesicular-arbuscular mycorrhizae in the laboratory, greenhouse and field, p. 59-67. In: N.C. Schenk (cd.). Methods and principles of mycorrhizal research. Amer. Phytopathol. Soc., St. Paul, Minn.

Menge, J. A., H. Lembright, and E.L.V. Johnson. 1977. Utilization of mycorrhizal fungi in citrus nurseries. Proc. Intl. Sot. Citriculture $1: 129-132$

Mosse, B. 1973. Advances in the study of vesicular-arbuscular mycorrhiza. Annu. Rev. Phytopathol. 11:171-196.

Mosse, B. 1975. A microbiologist's view of plant anatomy, p. 39-66. In: N. Walker (cd.). Soil microbiology, a critical review. Butterworths, London.

Page, A.L. 1982. Methods of soil analysis. Part 2, chemical and microbial properties. 2nd ed. Amer. Soc. Agron., Madison, Wis.

Phillips, J.M. and D.S. Hayman. 1970. Improved procedures for clearing roots and staining parasitic and vesicular-arbuscular mycorrhizal fungi for rapid assessment of infection. Trans. Brit. Mycol. Sot. 55:158-161.

Quick, J. and J. Rible. 1960. Water, soil, plant tissue, tentative methods of analysis for diagnostic purposes. Agr. Ext. Lab., Univ. of Calif., Riverside.

Sanders, F. E., P.B. Tinker, R.L.B. Black, and S.M. Palmerley. 1977. The development of endomycorrhizal root system. I. Spread of infection and growth-promoting effects with four species of vesiculararbuscular endophyte. New Phytol. 78:257-268.

Schuman, G. E., M.A. Stanley, and D. Knudsen. 1973. Automated total nitrogen analysis of soil and plant samples. Soil Sci. Soc. Amer. Proc. 37:480-481.

Smith, S. E., D.J.D. Nicholes, and F.A. Smith. 1979. Effect of early mycorrhizal infection on modulation and nitrogen fixation in Trifolium subterraneum L. Austral. J. Plant Physiol. 6:305-316.

Warner, A. and B. Mosse. 1982. Factors affecting the spread of vesicular-arbuscular mycorrhizal fungi in soil. I. Root density. New Phytol. 90:529-536.

Waterer, D.R. and R.R. Coltman. 1989a. Response of lettuce to preand post-transplant phosphorus and pre-transplant inoculation with VA-mycorrhizal fungus. Plant \& Soil 117:151-156.

Waterer, D.R. and R.R. Coltman. 1989b. Response of mycorrhizal bell peppers to inoculation timing, phosphorus, and water stress. HortScience 24:688-690. 